VLADIMIR POPOVIĆ, M.Sc. ${ }^{1}$

E-mail: msv.popovic@gmail.com

PAVLE GLADOVIĆ, Ph.D. ${ }^{2}$

E-mail: anaipavle@gmail.com

MILICA MILIČIĆ, Ph.D. ${ }^{2}$

E-mail: mmilica@uns.ac.rs

MILAN STANKOVIĆ, M.Sc. ${ }^{1}$

E-mail: milanst08@gmail.com

${ }^{1}$ College of Applied Technical Sciences Niš

Aleksandra Medvedeva 20, 18000 Niš, Serbia

2 University of Novi Sad, Faculty of Technical Sciences

Trg D. Obradovića 6, 21000 Novi Sad, Serbia
Traffic in the Cities

Preliminary Communication

Submitted: 2 May 2017

Accepted: 10 July 2018

\title{
METHODOLOGY OF SELECTING OPTIMAL FARE SYSTEM FOR PUBLIC TRANSPORT OF PASSENGERS
}

\begin{abstract}
According to the European Committee (EC) on Transport, the future road transport strategy lies in creating a strong road transport sector which is based on a well-functioning internal market, fair competition and workers' rights, decarbonization, and use of digital technologies. Urban and suburban passenger transportation systems, according to the principles of the EC, have a key role in achieving the goal of sustainable development and sustainable transport in cities. The fare, ticketing, and payment modes have a significant impact on public urban transport systems, primarily in terms of collecting transport service fees, and represent the basic source of financing of such systems, in addition to subsidies and grants from city budgets. This paper presents the selection methodology of the optimal fare system for urban public transport, applicable for all cities with an organized public city passenger transport (PCPT) system. Based on the established criteria with respect to setting tariff limits and fare systems, passenger demand, and the enterprise organizing the transport, the tariff system was selected. The presented method is that of multi-criteria optimization of the tariff system with numerical results on the example of the City of Novi Sad.
\end{abstract}

\section{KEY WORDS}

fare system; public passenger transport network; mathematical models; optimization;

\section{INTRODUCTION}

Each city with an organized public transport system faces the problem of selecting the optimal fare system for its network. The complexity of the task is reflected in the need to reconciliate the interests of passengers and organizers of transport. The applied fare system needs to consider the interest of the whole community as well. This means that the public transport fare system should be one of the best instruments for implementation of traffic policies in the city, which means favoring public over individual transport.
There are 4 models of tariff systems in public city passenger transport [1]: flat fare tariff system, zonal tariff system, sectional tariff system, and combined tariff system.

Having in mind that public passenger transport systems feature 3 groups of interests - the city, users, and transporters - this paper analyzes the aspect of the most valuable interest group - the user of the service, the passenger. From this point we analyze the possibility that this interest group pays the fare based on the length of the ride (travel). In that sense, the paper's limitations are related to the interests of the city and transporters, while the focus is on solving the problem of paying the optimal price of passenger transportation, based on ride (travel) length.

According to the recommendations of the European Committee, the core interest of contemporary cities is bigger use of public transportation compared to individual transport. In order to reach this goal, public transportation needs to be made more attractive, and one of the factors that can be used in this matter is introducing a fair transport price based on ride (travel) length.

To the best of our knowledge, the treatment of this problem has not been analyzed in the literature yet. Thus, we believe that this paper represents the beginning of analysis and solving of such problems.

The approach for optimal zonal tariff system selection requires intuitive-experiential consideration, i.e., a heuristic approach to solving the problem. Accordingly, this paper provides a method for multi-criteria optimization - VITAS, through which optimal solutions can be found. This method ranks the estimates of each variant, and the optimal one is that which ranks first in the ranking list. The evaluation of each variant is carried out according to the same procedure and according to precisely determined criteria. For the variants evaluation, 
it is necessary to adopt some convention. In this case, the adopted convention was to assign maximum score to the most favorable variant.

From the point of billing, a unified tariff system provides the best opportunity for the introduction of a rational system of fare collection, because it simplifies billing and reduces the number of billing types. Such tariff system was mostly applied in former Yugoslav cities, while, according to the data, the zonal tariff system is mostly applied in European cities.

During the introduction of modern billing systems, cities with relational tariff systems had the most issues, since a large number of billing types raises a problem with the issuance and annulment of tickets and control of passengers. To some extent, the problem can be simplified by reducing the number of relations (e.g. English towns). Also, certain simplifications in terms of reducing the number of billing types can be achieved with the zonal tariff system, but the fact is that it is much easier to rationalize the billing systems in cities that have a single tariff system than in cities with zonal and relational systems.

Clarke [2] considers the development of a fare system for several types of public transport in parallel. There are two main approaches for a multi-modal fare system. The first implies an unlimited number of rides in any type of transport within the defined zonal fare system, whereas the second implies that passengers pre-pay a certain amount to use public transport, and using modern ticketing systems the remaining sums are reduced proportionally by the value of each ride. In certain cities there is only one transport zone, in order to avoid complex technology, but the time of a single ticket use is limited by the introduction of the so-called time zone [1]. The author states that the development of electronic devices enables faster introduction of a multi-modal system.

Bonsall [3] presented the experience of Ottawa, where the transport management, based on a survey of travel characteristics, proposed a new fare system. The factors influencing the level of fares were analyzed, along with the aims of the fare system and transport prices before the implementation of the new fare system, the trends in expanding the mean length of travel and various fare systems. A new fare system proposal with various prices of tickets, depending on the line type (regular, express) and time of day, was presented.

Gladovic [4] analyzed the basic types of fare systems in different cities worldwide, as well as factors influencing the selection of the appropriate fare system type. Based on statistical parameters obtained by counting and passenger survey on public transport lines, the necessary and sufficient conditions for the selection of the optimal fare system were defined.

When selecting the optimal fare system, several general principles need to be considered [4]: a) From the aspect of passengers, the fare system needs to:

- Correspond to the needs of passengers and character of the line network,

- Consider differences and transport needs of certain categories of passengers as well as their social status,

- Correspond to natural flows of passengers,

- Motivate latent needs for moving,

- Be simple and easily acceptable for passengers.

b) From the aspect of an enterprise organizing the transport, the fare system needs to:

- Provide optimal income for the provided transport service,

- Be simple and easy to apply,

- Maintain certain relations between transport demands of passengers and the scope of transport,

- Support the overall development of the public transport in the city,

- Enable easy transfer to a more modern and rational system of fare collection.

Based on all this, the fare system, as a connection between transport demand of passengers and offered transport capacities, is the sum of the principles based on which the compensation that passengers pay for the provided transport services is calculated, along with the method of payment.

Section 1 of this paper presents the problem along with previous attempts at research. The Section 2 is dedicated to the methodological scopes for creating the optimal fare system, whereas Section 3 considers the selection of the fare system type. The method for multi-criteria optimization of the fare system is presented in Section 4. Section 5 describes the results of the methodology tested on the example of one city. The final considerations are presented in Section 6.

\section{METHODOLOGICAL FRAMEWORKS FOR CREATING THE OPTIMAL FARE SYSTEM}

Starting from the general principles for creating an optimal fare system, as well as the experience of certain cities, this paper presents a new approach to solving the addressed problem. Figure 1 provides a systematic presentation of the selection methodology of the optimal fare system for public transport lines in our approach. The implementation of this methodology requires defining the criteria to establish the fare system. This paper selects two criteria that can be applied to networks of both urban and suburban lines.

The first group of criteria are:

1) Mean length of ride $-L S R_{v}$

This criterion represents an average distance over which one passenger is transported along one line or the whole network, or an average distance that a passenger travels during one ride in a public transport (PT) vehicle. 


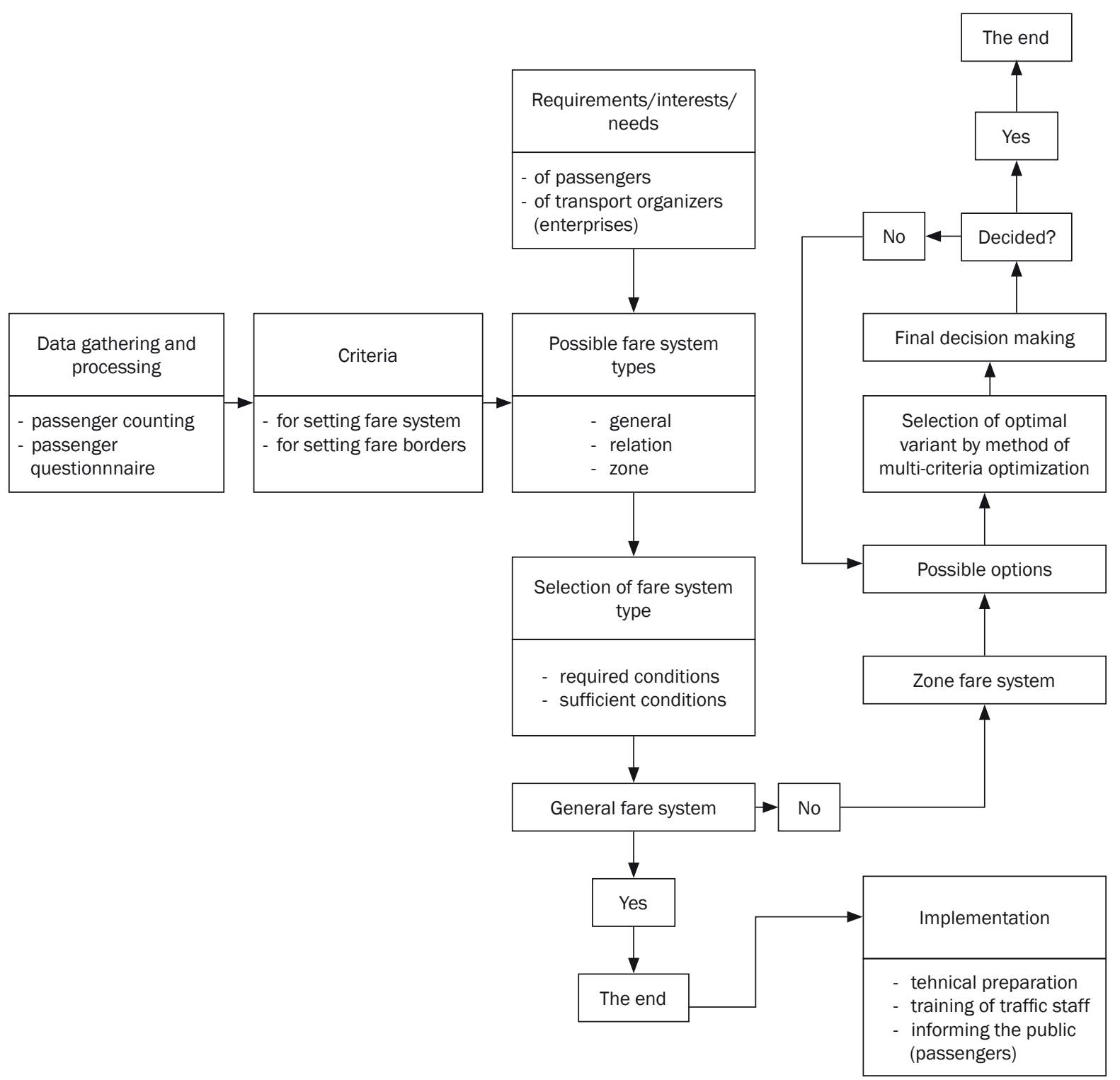

Figure 1 - Optimal fare system selection methodology for public transport lines

2) Mean length of travel of passengers - $L S R_{p}$ This criterion is the medium distance that an average passenger travels moving from the starting point to the final point of his/her trip, and it consists of: length of walk from the starting point to the entry stop, length of ride on one or more PT lines (in case of changing lines), and length of walking from the exit stop to the final point.

The second group of criteria refers to setting the fare limits. They are:

1) Entries and exits of passengers by stops

Calculation of the value of this criterion per line is necessary for defining stops with more frequent entries and exits of passengers. Identification of these stops is necessary for correct setting of fare limits. As a rule, the selected stop for the fare limit is the one with a significant number of passengers.
2) Changes of passengers

This criterion indicates the change of passengers comparing to previous or the following stop on the observed line.

\section{FARE SYSTEM TYPE SELECTION}

The basic fare system types applied in the public transport network are: general, zonal, and relational. Apart from the three basic types of the fare systems, there are mixed fare systems in some cities, representing various combinations of the basic types. Zonal and relation fare systems are performance-based. The fare in these systems depends on the length of travel.

In most cities worldwide there is a significant trend of abandoning the relation fare system, so it will not be separately addressed [4]. 
The general fare system is applicable in small towns and is a good choice if the mean lengths of rides (travel) are equal to the most frequent or common length of ride (travel). It is necessary to indicate in which case to select general, and in which case to select zonal fare system.

The mean length of ride (travel) is a random variable, and the descriptive measures most frequently used to describe its distribution are medium value and dispersion. The most frequent measure of central tendency is the mean value, and where input data is presented with classes of intervals, it is determined by the following formula [5]:

$\mu=x_{e}+i \frac{\sum n f}{N},\left(\sum_{i=1}^{n} f=N\right)$

If $x_{s}>x_{e}$ or $x_{s}<x_{e}$, then:

$\mu=x_{s}+i \frac{\sum n f}{N},\left(\sum_{i=1}^{n} f=N\right)$

where:

$N$-total number of passengers

$x_{e}$-mean of the interval class of the ride (travel)

length, coded as zero, i.e., for which $n=0$

$x_{s}$-mean of the interval class of the ride (travel)

length, coded for $x_{s}>x_{e}$ with $1,2,3, \ldots$, or for $x_{s}<x_{e}$

with $-1,-2,-3, \ldots$

$n$-number of interval class from $x_{e}$

$i$-width of interval class of length of ride (travel)

$f$-frequency of certain values $x_{s}$.

The mean length of a ride (travel) represents one of the most significant parameters to describe the center of dispersion of a random variable. Apart from the mean value and mode $(\mathrm{Mo})$, it represents a characteristic of the dispersion center of the length of ride. The mode Mo denotes its most probable value, or the value whose frequency is highest and is calculated based on the formula:

$M o=l_{m}+i \frac{1}{\delta_{1}+\delta_{2}}$

where:

$l_{m}$-the left limit of the interval class corresponding with the highest frequency

$\delta_{1}$-the difference between previous and modal

frequency

$\delta_{2}$-the difference between modal and following frequency

If the distribution of the mean length of ride (travel) is symmetrical to the dispersion center, then the mean value and mode are the same:

$\mu=M o$

In that case, the condition for adopting the general fare system is fulfilled. To establish the adequate condition, the parameters that measure the distribution of the random variable around the dispersion center need to be analyzed. The simplest measure of the random variable value dispersion is variance $\sigma^{2}$, calculated by the formula [5]:

$\sigma^{2}=i^{2}\left[\frac{\sum n^{2} f}{N}-\left(\frac{\sum n f}{N}\right)^{2}\right]$

If the analysis of the mean ride (travel) length distribution establishes that standard deviation is of a low value, then the general fare system could be applied. As it turns out, the performed numerical experiments have shown that the sufficient condition for application of the general fare system can be expressed through the requirement not to have less than $85 \%$ of the random variable describing the mean length of ride (travel) in the interval $\mu \pm \sigma$ [4]. In order to analyze the application of a general fare system, it is sometimes better to consider the coefficient of asymmetry $K_{A}$, or the excess coefficient $K_{E}$. The carried out statistical analyses indicate that the required and appropriate condition for the application of the general fare system can be expressed through the set of inequalities [4]:

$\left|K_{A}<0.25\right|$ and $K_{E}>0$

If the above conditions are not fulfilled, then the zonal fare system should be applied to the PT network. It should be constructed in the function of the mean length of travel and mean length of ride.

The zone limit should be tied to the mean length of travel representing one of the significant characteristics of travel in a city [6]. It is a function of city size, as well as the zones of residence and work, so its value is specific for each city.

On the other hand, the zone limit should be tied to the mean length of ride, which also represents a significant parameter of characteristics of passengers moving on the line. It also represents a specificity of the network of each town, as it is an average distance at which one passenger is transported on a line or the whole PT network.

\section{THE METHOD OF ZONAL FARE SYSTEM MULTI-CRITERIA OPTIMIZATION}

\subsection{Zonal fare system construction}

The zonal fare system in a public transport network (city and suburban lines) is constructed on the basis of mean ride length and mean travel length values. Suburban transport in each city is an organic whole with the transport of passengers in the city, as travel motifs and character are identical, so it could be combined with the fare of the city area. On the other hand, construction of zones in a suburban network should be a logical continuation of the city line zones, which can be beneficial from the aspect of city expansion. 
Based on the listed characteristics, it is clear that the same principles should be used for creating the zonal fare system for both city and suburban lines. This paper will analyze the following possible variants: Variant 1: In the function of the established value $L S R_{v}$, on the entire network

Variant 2: In the function of the established value $L S R_{p}$, on the entire network

Variant 3: In the function of the established value $L S R_{v}$, separately for city and suburban networks Variant 4: In the function of the established value $L S R_{p}$, separately for city and suburban networks

The problem of selecting the optimal zonal fare system requires intuitive-empirical reviews, or the heuristic approach. The heuristic methods are based on specific standpoints significantly influencing the character of these methods as well as terms of application. This paper represents the combination of exact and heuristic approaches, and its efficiency will be shown on a numerical example.

The construction of the zonal fare system on a complete public transport network is preliminarily designated by a group of circles, from the inner to the outer circle - zone. The radius of the first circle is: $R_{1}=\frac{L S R_{v}}{2}$, or $R_{1}=\frac{L S R_{p}}{2}$. The radius of each next circle $R_{i}$, is $R_{i}=R_{i-1}+L S R_{v}$, or $R_{i}=R_{i-1}+L S R_{p}$, until the last circle comprising the last stop of the public transport network. Identification of the zone limits in zonal fare system construction is shown in Figure 2.

The analysis of elements presented in Figure 2 indicates that each circle does not intersect the public transport stops but passes through two neighboring stops, so it is necessary to establish at which of these two stops the zone limit should be set. The decision is based on the criterion for setting the fare limits.
According to this criterion, for the $L_{i}$ line the fare limit should be placed at the $m_{i+1}$ stop if the following condition is fulfilled:

$$
\sum_{i=1}^{n} U_{i, i+1}>\sum_{i=1}^{n} U_{i, i} \text { or } \sum_{i=1}^{n} I_{i, i+1}>\sum_{i=1}^{n} I_{i, i}
$$

whereas for the $L_{k}$ line the fare limit should be set at the $m_{k}$ stop when the following condition is fulfilled:

$\sum_{k=1}^{n} U_{k, k}>\sum_{k=1}^{n} U_{k, k-1}$ or $\sum_{k=1}^{n} I_{k, k}>\sum_{k=1}^{n} I_{k, k-1}$

The problem with adjacent stops in the central city zone with a high interchange of passengers should be solved by introducing neutral zones, or using the criterion of the exchange of passengers. On the $L_{j}$ line a neutral zone should be introduced between the stops $m_{j}$ and $m_{j+2}$ if the Conditions 8 and 9 are fulfilled.

$\sum_{j=1}^{n} l_{j} \leq \frac{L S R_{2}}{2}$

where $n$ is the number of distances between stops. Or if,

$$
I Z M_{j}=I Z M_{j+2}
$$

where $I Z M_{j}$ stands for exchange of passengers on stop $j$ during one day.

In Relation 8, instead of $L S R_{v}$, it is possible to use the alternative $L S R_{p}$. The problem of circular and tangential lines should be solved by introducing segments within zones, with segment width approximately corresponding to the $L S R_{v}$ or $L S R_{p}$ size. According to the zonal fare system construction, the following elements for each variant should be established:

- Arithmetic mean of the number of zones per line

- Standard deviation of the number of zones per line

- Arithmetic mean of the zone width per line

- Standard deviation of the zone width per line

- Variation coefficient, relation between the zone width standard deviation and arithmetic mean of the zone width per line

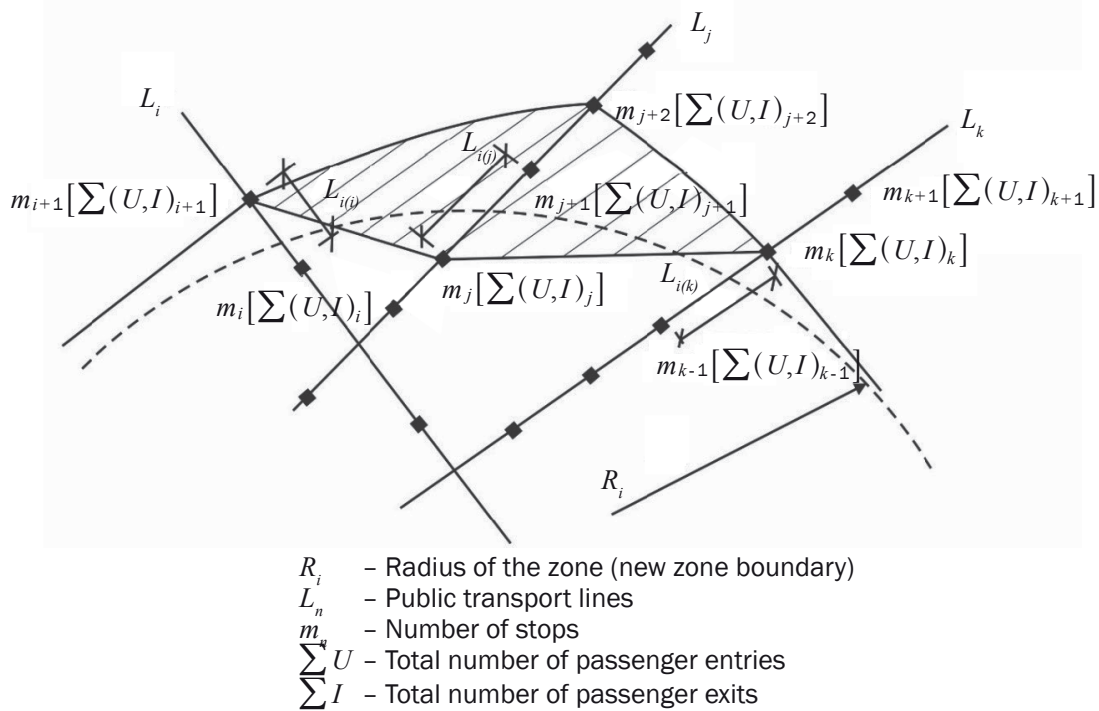

Figure 2 - Identification of the zone limits for constructing the zonal fare system 


\subsection{Multi-criteria optimization and the VITAS method}

For the multi-criterion optimization of the zonal fare system, the five-stage VITAS method was defined, based on which the variants of the zonal fare system are ranked. The optimal variant is the one with the highest score (grade) of the variation coefficient. The evaluation of each variant is carried out according to the same procedure and the already established criteria. In this method, the adopted convention is that the maximum score is given to the most favorable variant. The VITAS method algorithm consists of the following five steps:

Step 1 - Selecting the criteria and defining criteria values

For the VITAS method, the following four criteria have been selected:

$\overline{B Z}$-arithmetic mean of the number of zones per line,

$K V B$ - variation coefficient $\left(K V B=\frac{S B Z}{B Z}\right)$

where $S B Z$ is the standard deviation of the number of zones per line,

$E$-relative deviation of the arithmetic mean of the length of zone per line $(\overline{S Z})$ compared to the mean length of ride $\left(L S R_{v}\right)$ or mean length of travel $\left(L S R_{p}\right)$, calculated by the following relations:

- in case of zonal fare system construction based on the mean length of ride $\left(L S R_{v}\right)$ :

$E=\frac{\left|\overline{S Z_{v}}-L S R_{v}\right|}{L S R_{v}}$

- in case of zonal fare system construction based on the mean length of ride $\left(L S R_{p}\right)$ :

$E=\frac{\left|\overline{S Z_{p}}-L S R_{p}\right|}{L S R_{p}}$

where: $\overline{S Z_{v}}$ is the arithmetic mean of the zone width per line in construction of the zonal fare system based on $L S R_{v} ; \overline{S Z_{p}}$ is the arithmetic mean of the zone width per line in zonal fare system construction based on $L S R_{p}$.

$K V S$ - variation coefficient $\left(K V S=\frac{S S Z}{S Z}\right)$

where $S S Z$ is the standard deviation of the zone width per line.

The values of each criterion are established in each option according to the zonal fare system construction, separately for city and suburban networks of public transport lines, when the numerical values of the approved parameters defining the selected criteria have been obtained. All the criteria should be minimized.

\section{Step 2 - Normalization of the criteria values}

Before evaluating each criterion, it is necessary to perform the 'normalization' of the criteria values calculated in the previous step.
In this step, the values of each criterion are within the 0 to 1 interval to enable a unique and independent treatment of each criterion, as an objective base for the final evaluation of variants.

First, maximal and minimal values need to be established for each criterion by assigning 1 for the maximum criterion value and 0 for the minimum criterion value.

Normalized values of defined criteria $N V K_{i j}$ are calculated by the following relation:

$$
N V K_{i j}=\frac{\left|X_{i j}-\max X_{i j}\right|}{\left|\max X_{i j}-\min X_{i j}\right|}
$$

where: $X_{i j}$ is the calculated value of criterion $i$ for variant $j ; i=1,2, \ldots, m$ is the number of criteria; $j=1,2, \ldots$; $J$ is the number of constructed variants of the zonal fare system in the public transport network.

\section{Step 3 - Determining the criterion rank}

When assessing the criterion rank of difficulty in case where several influential criteria are acting and they are different by intensity and direction of influence, there is a problem of determining the influence of the selected criteria.

Due to the complexity of the selected criteria which cannot be mathematically modeled due to various reasons, it is necessary to establish the influence of each criterion in this step only based on experience. The method of the analytical expert evaluation sets the following values of criterion $W_{i}$ (weights of criteria $K V B, E$, etc.) [5]:

$W_{1}=0.3$ (for criterion $(\overline{B Z})$ ),

$W_{1}-W_{2}=0.1$ (for criterion $K V B$ ),

$W_{1}-W_{3}=0.3$ (for criterion $E$ ),

$W_{1}-W_{4}=0.3$ (for criterion $K V S$ ),

Therefore, these criteria $W_{i}$ are actually the weights of the criteria $K V B, E$, etc.

Provided that:

$$
\sum_{i=1}^{4} W_{i}=1, i=1, \ldots, 4
$$

Step 4 - Determining evaluation of each option

The evaluation of each variant of the zonal fare system that takes into account all four criteria and their significance (difficulty of criterion) is defined by the following expression:

$$
O V_{j}=\sum_{i=1}^{4} N V K_{i j} \cdot W_{i}, j=1,2, \ldots, J
$$

where $O V_{j}$ is the evaluation of the option (variant) $j$ of the zonal fare system, provided that $\max _{N V K_{i j}}=1$, $\min N V K_{i j}=0,0<N V K_{i j}<1$, and $\sum_{i=1}^{4} W_{i}=1$.

Step 5 - Ranking evaluations of variants and selection of optimal variant

This step provides the ranking of all evaluations of the zonal fare system variants according to the adopted convention that the rank of an option is higher if 
the evaluation is higher. The option that is at the top of the list obtained in such a way is the optimal variant of the zonal fare system that should be adopted for the public transport network in a respective city.

\section{NUMERICAL EXAMPLE}

The above methodology for selection of optimal fare system was tested on the public transport lines in Novi Sad, Serbia. Public transport in this city is performed across 18 city lines and 35 suburban lines covered by buses. The total length of the city lines is $201.3 \mathrm{~km}$, and of the suburban ones $1523.04 \mathrm{~km}$. In May 1989, there was a general counting of the number of passengers on the entire public transport network, along with a questionnaire for passengers at the public transport stops, with the sample of $9.8 \%$ of the total number of transported passengers. [7]

Based on the results of the general counting and passenger survey for the public transport of Novi Sad, the following characteristics of passengers were established [5]:

- Mean length of ride in the city network is $2.519 \mathrm{~km}$,

- Mean length of ride on the suburban network is $9.936 \mathrm{~km}$,

- Mean length of ride on the entire network of lines is $4.992 \mathrm{~km}$,
- Mean length of travel on the city network is 4.349 $\mathrm{km}$,

- Mean length of travel on the suburban network is $12.728 \mathrm{~km}$,

- Mean length of travel on the entire network is $7.528 \mathrm{~km}$.

On the city and suburban networks, as well as on the entire network, there are significant differences related to the mean lengths of ride and travel, observed separately for each line. This indicates the issues of the applied general fare system for the city lines and the relation fare system for the suburban lines, as well as the issue of further expansion of the city. Table 1 presents statistical parameters obtained by the survey among passengers using the public transport in Novi Sad.

The results from Table 1 indicate that there is significant deviation between mode and arithmetic mean, as well as between values of $K_{A}$ and $K_{E}$, so the solution of the optimal fare system should be looked for in the application of the zonal fare system to both the city and suburban networks. Based on the defined criteria for setting the fare system, the zonal fare system was constructed separately on the city and suburban networks, and the results are presented in Tables 2 and 3.

Table 1 - Statistical parameters obtained by the survey of passengers using the public transport in Novi Sad

\begin{tabular}{||l|c|c|c||}
\hline \multicolumn{1}{|c|}{ Type of parameter } & City lines & Suburban lines & Entire network \\
\hline \hline Arithmetic mean $\mu$ & 4.349 & 12.728 & 7.582 \\
\hline Standard deviation $\sigma$ & 3.533 & 6.179 & 6.481 \\
\hline Mode $M o$ & 2.697 & 8.513 & 5.827 \\
\hline Variation coefficient $K_{V}$ & 0.8124 & 0.4855 & 0.8548 \\
\hline Asymmetry coefficient $K_{A}$ & 0.513 & 0.407 & 0.623 \\
\hline Excess coefficient $K_{E}$ & 0.741 & 0.933 & 0.872 \\
\hline
\end{tabular}

Table 2 - Basic elements of the zonal fare system by options construction - city lines

\begin{tabular}{|c|c|c|c|c|c|c|c|c||}
\hline $\begin{array}{c}\text { Variant } \\
\text { (option) }\end{array}$ & $\begin{array}{c}\text { Total number } \\
\text { of zones }\end{array}$ & $\overline{B Z}$ & $S B Z$ & $K V B$ & $\overline{S Z}$ & $E$ & $S S Z$ & $K V S$ \\
\hline \hline I & 29 & 1.61 & 0.87 & 0.5403 & 5.96 & 0.194 & 3.517 & 0.5901 \\
\hline II & 26 & 1.44 & 0.93 & 0.6458 & 8.72 & 0.150 & 4.841 & 0.5582 \\
\hline III & 38 & 2.11 & 0.57 & 0.2701 & 3.21 & 0.274 & 1.134 & 0.3533 \\
\hline IV & 31 & 1.72 & 0.65 & 0.3779 & 4.04 & 0.067 & 1.832 & 0.4535 \\
\hline
\end{tabular}

Table 3 - Basic elements of the zonal fare system by options construction - suburban lines

\begin{tabular}{||c|c|c|c|c|c|c|c|c||}
\hline $\begin{array}{c}\text { Variant } \\
\text { (option) }\end{array}$ & $\begin{array}{c}\text { Total number } \\
\text { of zones }\end{array}$ & $\overline{B Z}$ & $S B Z$ & $K V B$ & $\overline{S Z}$ & $E$ & $S S Z$ & KVS \\
\hline \hline I & 162 & 4.63 & 1.29 & 0.2786 & 4.39 & 0.121 & 2.619 & 0.5966 \\
\hline II & 248 & 7.09 & 2.02 & 0.2849 & 6.41 & 0.154 & 3.117 & 0.4863 \\
\hline III & 126 & 3.60 & 0.65 & 0.1805 & 9.72 & 0.022 & 3.431 & 0.3530 \\
\hline IV & 113 & 3.23 & 0.57 & 0.1765 & 13.81 & 0.085 & 4.018 & 0.2909 \\
\hline
\end{tabular}


Table 4

\begin{tabular}{|c|c||}
\hline Variants (city lines) & Variant evaluation \\
\hline \hline I & 0.5756 \\
\hline II & 0.3916 \\
\hline III & 0.7500 \\
\hline IV & 0.3325 \\
\hline
\end{tabular}

Table 5

\begin{tabular}{||c|c||}
\hline \hline Variants (suburban lines) & Variant evaluation \\
\hline \hline I & 0.4594 \\
\hline II & 0.9041 \\
\hline III & 0.1195 \\
\hline IV & 0.2353 \\
\hline
\end{tabular}

The option evaluation ranking was done using the VITAS method. The evaluations of all the options are presented in Tables 4 and 5. Based on the results for the city lines, the third option should be selected, whereas in the case of the suburban lines it is best to apply the second option of the zonal fare system.

\section{CONCLUSION}

The paper presents the fare system selection methodology for public transport networks and discusses its advantages and disadvantages. It analyzes the basic types of the fare systems and defines the criteria for the implementation of the new fare system method introduced in this work. The construction of the zonal fare system has been presented, and the optimizing method based on multi-criteria optimization has been illustrated for this system. The multi-criteria optimization of the zonal fare system method is based on the VITAS method, where different variants of the zonal fare system are ranked. The VITAS method algorithm consists of five steps: (1) selecting criteria and defining criteria value, (2) normalization of the criteria values, (3) determination of the criterion rank, (4) determination of evaluation of each option, and (5) ranking evaluations of variants and selection of optimal variant. The developed procedures have proved to be appropriate, and their validity was demonstrated on the example of the City of Novi Sad. According to the parameters obtained by a survey of passengers using the public transport in Novi Sad, the results indicate that the solution for the optimal fare system should be sought in the application of the zonal fare system on both city and suburban networks. Evaluation of all options has been presented, and by applying the VITAS method the authors have shown which options are the most suitable for selection. There are wide options for a public transport company to find the best ways to optimally organize traffic so as to enable business operations with minimal expenditures. The further development of the VITAS method should include the application of modern information technologies in the tariff system as a powerful tool for automatic traffic management, collection, and storage of large quantities of information. This will secure all technological conditions to significantly increase public transport efficiency in the future. In addition, such improved use of the VITAS method will enable providing reliable information about passengers' trips on certain routes.

VLADIMIR POPOVIĆ, M.Sc. ${ }^{1}$

E-mail: msv.popovic@gmail.com

PAVLE GLADOVIĆ, Ph.D. ${ }^{2}$

E-mail: anaipavle@gmail.com

MILICA MILIČIĆ, Ph.D. ${ }^{2}$

E-mail:mmilica@uns.ac.rs

MILAN STANKOVIĆ, M.Sc. ${ }^{1}$

E-mail: milanst08@gmail.com

${ }^{1}$ Visoka tehnička škola

Aleksandra Medvedeva 20, 18000 Niš, Srbija

2 Univerzitet u Novom Sadu, Fakultet tehničkih nauka

Trg D. Obradovića 6, 21000 Novi Sad, Srbija

\section{METODOLOGIJA IZBORA OPTIMALNOG TARIFNOG SISTEMA U JAVNOM GRADSKOM PREVOZU PUTNIKA}

\section{APSTRAKT}

Prema evropskoj komisiji (EK) za saobraćaj, buduća strategija drumskog saobraćaja je u stvaranju jakog transportnog sektora, koji se zasniva na dobro funkcionalnom unutrašnjem tržištu, poštenoj konkurenciji i pravima radnika, dekarbonizaciji i korišćenju digitalnih tehnologija. Sistemi gradskog i prigradskog prevoza putnika, prema principima EK, imaju ključnu ulogu u postizanju cilja održivog razvoja i održivog transporta u gradovima. Tarifni sistem, sistem karata i sistem plaćanja imaju značajan uticaj na javni gradski transportni sistem, pre svega zbog naplate naknade za uslugu prevoza, a predstavljaju osnovni način finansiranja sistema pored subvencija i grantova iz gradskog budžeta. Ovaj rad predstavlja metodologiju odabira optimalnog tarifnog sistema za mrežu javnog prevoza u gradovima, koji je moguće primeniti u svim gradovima sa organizovanim sistemom javnog gradskog prevoza putnika (JGPP). Na osnovu utvrđenih kriterijuma, prvo za utvrđivanje tarifnih limita $i$ tarifnih sistema, a potom zahteva putnike i preduzeće koje organizuje prevoz, izvršen je izbor tarifnog sistema. Prikazana metoda je metoda višekriterijske optimizacije tarifnog sistema sa numeričkim rezultatima na primeru Grada Novog Sada.

\section{KLUUČNE REČI}

tarifni sistem; javni gradski prevoz putnika; mreža linija; matematički modeli; optimizacija;

\section{REFERENCES}

[1] Banković R. Organizacija i tehnologija Javnog Gradskog Putničkog Prevoza. Saobraćajni fakultet Univerziteta u Beogradu; 1994. Serbian

[2] Clarke WR. Development in Multi-Modal Ticketing. 
Public Transport International. 1993;4: 15-19.

[3] Bonsall JA. Vers un système tarifaire plus équitable et plus rentable? l'expérience d'Ottawa: tarifs modulés selon Í'heure de la journée. Public Transport International. 1988;1: 11-39. French

[4] Gladović P. Tarifna politika u Javnom Gradskom Putničkom Prevozu. $1^{\text {st }}$ ed. Beograd: PC Program; 1995. Serbian

[5] Stojaković M. Verovatnoća i matematička statistika. $1^{\text {st }}$ ed. Novi Sad: Fakultet tehničkih nauka Univerziteta u Novom Sadu; 1997. Serbian

[6] Torgusen F, Gerard M. Fare Systems and Fare Collection - Recent Development and Future Aspects. 46 $6^{\text {th }}$ International VITP Congress, Brisel; 1985.

[7] Fakultet tehničkih nauka Univerziteta u Novom Sadu. Analiza i ocena sistema javnog gradskog i prigradskog prevoza putnika u Novom Sadu, Novi Sad, 2011. Serbian
[8] Gladović P, Popović V, Peulić V. Expenditure model of line ranking in te Public Mass Passenger Transportation System. Promet - Traffic \& Trasportation. 2011;23(6): 503-509.

[9] Marić V, Kavran Z, Kovačević D. Traffic and planning aspects of public urban transport. Promet - Traffic Traffico. 2004;16(3): 145-149.

[10] Krajnc R, Sever D. Model approach to quality provision of public passenger transport. Promet - Traffic \& Trasportation. 2010;22(1): 65-74.

[11] Popovic V, Stankovic M, Gladovic P. Needs for application of modern fare systems in public city passenger transport. First internacional conference Transport for today`s society, Bitola, FYRM. 2016; p. 333-341.

[12] GIZ (Deutsche Gesellschaft für Internationale Zusammenarbeit). Sustainable transport evaluation, Technical document, 2011. 